\title{
Transforming growth factor- $\beta$ induces growth inhibition and IGF-binding protein-3 production in prostatic stromal cells: abnormalities in cells cultured from benign prostatic hyperplasia tissues
}

\author{
P Cohen ${ }^{1}$, S E Nunn ${ }^{1}$ and D M Peehl ${ }^{2}$ \\ ${ }^{1}$ Pediatric Endocrinology, UCLA, Los Angeles, California 90095, USA \\ ${ }^{2}$ Urology, Stanford University School of Medicine, Stanford, California 94305, USA \\ (Requests for offprints should be addressed to P Cohen, Division of Endocrinology, Department of Pediatrics, Mattel Children's Hospital at UCLA, \\ 10833 Le Conte Avenue, MDCC 22-315, Los Angeles, California 90095-1752, USA; Email: hassy@mednet.ucla.edu)
}

\begin{abstract}
The IGF axis has been implicated in the pathogenesis of benign prostatic hyperplasia $(\mathrm{BPH})$ via the paracrine action of IGFs and IGF-binding proteins (IGFBPs). In this study, we examined the regulation of cell growth and IGFBP-3 secretion by transforming growth factor- $\beta$ $(\mathrm{TGF}-\beta)$ in prostatic stromal cell (PC-S) cultures from histologically normal tissues and tissues from BPH. PC-S cultures were treated with varying doses of TGF- $\beta 1$. Forty-eight hour conditioned media (CM) from these cultures were subjected to Western immunoblotting and ligand blotting for detection and quantification of IGFBPs. IGFBPs-2, -3 and -4 were detected in the $\mathrm{CM}$ from normal PC-S cultures. In CM from $\mathrm{BPH}$ PC-S, IGFBP-3 levels were 2-fold lower at baseline than in the normal PC-S CM, in addition to the differences in IGFBPs- 2 and -5 which we have previously reported. In response to TGF- $\beta 1$, a 15 -fold increase in the levels of IGFBP-3 was observed in normal PC-S CM, while a mere 2-fold increase was observed in BPH PC-S CM $(P<0 \cdot 001)$. These findings were confirmed by specific
\end{abstract}

immunoblotting and immunocytochemistry. IGFBP-3 mRNA levels detected by Northern blotting of total RNA extracted from similar cultures showed the induction of IGFBP-3 expression by TGF- $\beta 1$ in normal PC-S and its lack of induction in BPH PC-S. Cell growth inhibition in response to TGF- $\beta 1$ correlated with the IGFBP-3 concentrations found in CM. Normal PC-S showed a $60 \%$ decrease in cell number after 10 days in media with $1 \mathrm{ng} / \mathrm{ml}$ TGF- $\beta 1$, compared with the untreated control. The decrease in proliferation observed in comparably treated BPH cells was only $20 \%(P<0 \cdot 001)$. In conclusion, BPH PC-S had a reduced IGFBP-3 response to TGF- $\beta 1$ and demonstrated decreased TGF- $\beta 1$-induced growth inhibition relative to normal PC-S. We hypothesize that in normal PC-S, TGF- $\beta$ exerts its anti-proliferative effects by stimulating the production of IGFBP-3, which acts as an inhibitory factor, either by inhibiting IGFs or directly by interacting with cells, and that this process is altered in BPH PC-S.

Journal of Endocrinology (2000) 164, 215-223

\section{Introduction}

The insulin-like growth factor (IGF) axis consists of IGF-I and IGF-II, the type I and type II IGF receptors, and six known IGF-binding proteins (IGFBPs-1 to -6). Locally produced IGFs and IGFBPs regulate tissue growth and differentiation (Solberg \& Cohen 1996). The IGFBPs are thought to modulate the action of IGFs in several ways, including an inhibitory model in which IGFBPs sequester IGFs from their receptors (Angervo et al. 1991, Cohen et al. 1993), an enhancing model in which IGFBPs transport IGFs to their site of action (Elgin et al. 1987, Conover 1992, Neuenschwander et al. 1996), or an IGF-independent model that may involve direct inter- action of IGFBPs with putative IGFBP receptors (Oh et al. 1993a,b, 1995, Valentinis et al. 1995, Angelloz-Nicoud et al. 1996, Gucev et al. 1996, Lalou et al. 1996, Gill et al. 1997, Rajah et al. 1997, Rechler 1997, Zadeh \& Binoux 1997), which mediate the growth inhibitory effects of the IGFBPs. IGFBPs are regulated by various endocrine factors and are expressed in specific ontogenic patterns (Solberg \& Cohen 1996). In the prostate gland, IGFs and IGFBPs appear to play an important role in the proliferative processes that lead to benign prostatic hyperplasia (BPH) and prostate cancer (Cohen et al. 1994b). We have previously demonstrated that prostatic stromal cell (PC-S) cultures from tissues with $\mathrm{BPH}$ harbor numerous changes in the IGF axis (Cohen et al. 1994a,b, Dong et al. 1997). 
These changes include a decrease in the levels of the tumor suppressor transcription factor WT-1 leading to increased expression of IGF-1 receptor and IGF-II (Guo et al. 1995) as well as a loss of IGFBP-2 and a gain in IGFBP-5 secretion from PC-S (Cohen et al. 1994b).

Transforming growth factor- $\beta$ (TGF- $\beta$ ) has been demonstrated in previous studies to be a potent regulator of IGFBP production by various cell types (Martin \& Baxter 1991, Martin et al. 1992, Yateman et al. 1993, Cazals et al. 1994, Durham et al. 1994, McCusker \& Clemmons 1994, Tsukazaki et al. 1994, Guo et al. 1995, Han et al. 1997, Hwa et al. 1997, Rajah et al. 1997). In most cells, TGF- $\beta$ has been shown to be a potent stimulator of IGFBP-3 (Martin \& Baxter 1991, Martin et al. 1992, Yateman et al. 1993, Cazals et al. 1994, McCusker \& Clemmons 1994, Han et al. 1997, Hwa et al. 1997, Rajah et al. 1997). TGF- $\beta$ is also known to inhibit the growth of certain cells (Yateman et al. 1993, Oh et al. 1995, Rajah et al. 1997). Using a breast cancer model, Oh et al. (1995) demonstrated that the stimulation of IGFBP-3 by TGF- $\beta 2$ is critical to TGF- $\beta$-induced growth inhibition, and Rajah et al. (1997) showed that IGFBP-3 expression is necessary for TGF- $\beta 1$-induced apoptosis in a prostate cancer model. Several investigators suggest that IGFBP-3 acts directly through binding to specific cell surface receptors on susceptible cells (Conover 1992, Cohen et al. 1993, Oh et al. 1993a, 1995, Valentinis et al. 1995, Angelloz-Nicoud et al. 1996, Gucev et al. 1996, Lalou et al. 1996, Neuenschwander et al. 1996, Gill et al. 1997, Karas et al. 1997, Leal et al. 1997, Mohseni-Zadeh \& Binoux 1997, Rajah et al. 1997, Rechler 1997, Zadeh \& Binoux 1997).

In this study, we examined the effects of TGF- $\beta$ on growth and IGFBP-3 secretion of normal and BPH PC-S cultures with the hypothesis that the TGF-IGFBP-3growth axis is also aberrant in $\mathrm{BPH}$.

\section{Materials and Methods}

\section{Materials}

Iodinated IGF-I and -II were purchased from Amersham (Arlington Heights, IL, USA). Human IGFBP-3 antibodies purified on an IGFBP-3 affinity column were purchased from Diagnostic Systems Laboratories (Webster, TX, USA). TGF- $\beta 1$ was purchased from Promega Corp. (Madison, WI, USA). SDS-PAGE reagents were purchased from Sigma Chemical Co. (St Louis, MO, USA).

\section{Primary cell cultures}

Prostatic tissues were obtained from radical prostatectomy or open prostatectomy specimens and processed for cell culture as previously described (Peehl 1992, Peehl \&
Sellers 1997). The remainder of the prostate was fixed and serially sectioned. Normal cell cultures were derived from tissues with no evidence of $\mathrm{BPH}$ or cancer in the sections surrounding the wedge used for culture. BPH cell cultures were derived from $\mathrm{BPH}$ tissues with no cancer. Selective culture conditions allowed the establishment of pure stromal strains with no epithelial cell contamination. Stromal cells were maintained in MCDB 105 medium (Sigma) with $10 \%(\mathrm{v} / \mathrm{v})$ fetal bovine serum (FBS) and $100 \mu \mathrm{g} / \mathrm{ml}$ gentamicin. Five strains each of $\mathrm{BPH}$ and normal PC-S were used altogether. Derivation of pure stromal cells was achieved as follows. Tissue samples were minced and digested overnight in collagenase. After rinsing, the digested tissue fragments were inoculated into one 60-mm dish containing MCDB 105 medium supplemented with $10 \% \mathrm{FBS}$ and $100 \mu \mathrm{g} / \mathrm{ml}$ gentamicin. Dishes were incubated in a humidified atmosphere at $37^{\circ} \mathrm{C}$ with $5 \% \mathrm{CO}_{2} / 95 \%$ air. Generally both stromal and epithelial cells attached within 1 week. The cells were fed every 3 or 4 days until dishes contained abundant stromal outgrowth. During this period, degeneration of epithelial cells was common. Remaining epithelial cells were lost upon the first passage, which was achieved by rinsing the cells twice with Hepes-buffered saline and incubating for 2-3 min at $37^{\circ} \mathrm{C}$ with $0 \cdot 2 \%$ trypsin $/ 0.02 \%$ EDTA. Cells were resuspended with MCDB 105 containing 10\% FBS and gentamicin and briefly centrifuged. The cell pellet was resuspended in MCDB 105 with 10\% FBS and gentamicin and transferred to two $60-\mathrm{mm}$ dishes. These secondary cultures, free of epithelial cells, were grown to confluency, then frozen. Cells were thawed and passaged as needed for experimental purposes. Each cell strain was routinely characterized by immunocytochemical labeling and was found to be negative for cytokeratin and factor VIII, but positive for vimentin and fibronectin. Alpha-smooth muscle actin was generally present at low levels.

\section{Conditioned media (CM)}

CM were obtained from cell cultures grown to confluency in MCDB 105 with 10\% FBS. Cells were then washed twice with Hepes-buffered saline and incubated with serum-free media (with or without TGF- $\beta$ ) for $48 \mathrm{~h}$. Media were collected, centrifuged briefly, and stored at $-70{ }^{\circ} \mathrm{C}$ until analysis.

\section{Western ligand blots (WLB)}

Serum-free CM $(50 \mu \mathrm{l})$ was electrophoresed through non-reducing $12.5 \%$ polyacrylamide-SDS gels overnight at constant voltage, electroblotted onto nitrocellulose, sequentially washed with NP-40, blocked with $1 \%$ BSA in Tris-buffered saline, incubated with $10^{6}$ c.p.m. ${ }^{125}$ I-IGF-I and -II for $12 \mathrm{~h}$, then exposed to film for 5 days, as 
previously described (Cohen et al. 1991). Each lane of the autoradiographs was scanned and analyzed densitometrically.

\section{Western immunoblots (WIB)}

Detection of CM levels of IGFBP-3 was carried out in the same way as in WLB, except that the nitrocellulose was probed with IGFBP-3-specific antibodies (Diagnostic Systems) using a peroxidase-linked chemiluminescence detection system (Amersham) as previously described (Rajah et al. 1997).

\section{Northern blots}

Total RNA ( $20 \mu \mathrm{g} /$ lane) was electrophoresed through a $1 \%$ agarose-formaldehyde gel at constant voltage and capillary blotted onto Zeta-probe membrane (BioRad, Hercules, CA, USA). Membranes were probed overnight with ${ }^{32} \mathrm{P}-$ labeled IGFBP-3 cDNA fragment (amplified by PCR using primers for a $400 \mathrm{bp}$ fragment of the N-terminal region of human IGFBP-3), washed, and exposed to film as previously described (Cohen et al. 1991). RNA loading was controlled for by normalization to actin expression on the same blots. Blots were quantified with the aid of a phosphoimager (Molecular Dynamics, Atlanta, GA, USA).

\section{Immunocytochemistry}

Cells were inoculated at $5 \times 10^{3}$ cells per chamber in eight-chamber slides containing MCDB 105 with $10 \%$ FBS. Three days later, medium was changed to MCDB 105 without serum and with or without $1 \mathrm{ng} / \mathrm{ml}$ TGF- $\beta 1$. Four days later, cells were fixed with $2 \%$ paraformaldehyde and permeabilized with $95 \%$ ethanol. Non-specific binding was blocked with 10\% horse serum, then the cells were incubated with a polyclonal rabbit antiserum against IGFBP-3 (1:400) (Diagnostic Systems). Binding of the primary antibody was detected with biotinylated antirabbit IgG, the avidin-biotin complex reagent, and the substrate diaminobenzidine as previously described (Peehl \& Sellers 1997).

\section{Growth assays}

Cells were inoculated at 200 cells $/ 60 \mathrm{~mm}$ dish containing MCDB 105 with 10\% FBS and experimental factors. After 10 days of incubation, the cells were fixed and stained with crystal violet and relative growth was measured with an image analyzer as previously described (Cohen et al. 1991).

\section{Statistical analysis}

Experiments were performed in triplicates and repeated three times. Densitometric data were analyzed using

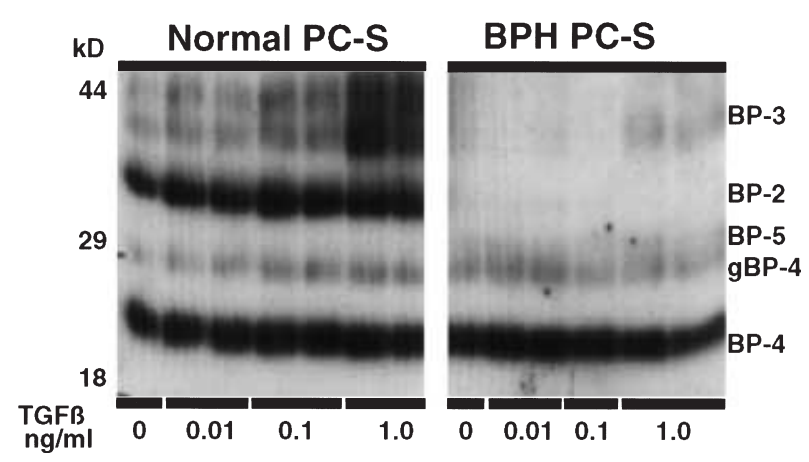

Figure 1 Demonstration of IGFBPs secreted from normal and BPH PC-S. WLB analyses of $48 \mathrm{~h}$ CM from normal and BPH stromal cell strains are shown. (gBP-4=glycosylated IGFBP-4.) CM (50 $\mu \mathrm{l})$ was electrophoresed on $12 \cdot 5 \%$ SDS-PAGE and visualized by autoradiography of ${ }^{125}$ I-IGF-I and -II bindings.

standard statistical methods, including Student's $t$-test and ANOVA. Results are reported as mean \pm s.E.M.

\section{Results}

\section{Detection of IGFBPs in PC-S CM}

We examined the levels of IGFBPs in PC-S CM obtained from confluent cultures maintained in serum-free medium for $48 \mathrm{~h}$. Figure 1 is an autoradiograph which demonstrates the various IGFBPs which are detectable by ${ }^{125}$ I-IGFlabeled WLB. IGFBPs- 2 to -5 were identifiable by their respective sizes and were confirmed by specific immunoblots (data not shown). In the control (untreated) lane of normal PC-S CM, bands representing IGFBPs-4, gly-4, -2 and -3 are visible, while in the control lane of $\mathrm{BPH}$ PC-S CM, IGFBP-2 $(31 \mathrm{kDa})$ is dramatically reduced in intensity while IGFBP-5 (24 kDa) becomes apparent, as we have previously published (Cohen et al. 1994a). IGFBP-4 (24 kDa) levels appear to be constant between the normal and BPH strains. Also noted is IGFBP-3 $(40-44 \mathrm{kDa})$, which is 2 -fold lower in $\mathrm{BPH}$ vs normal. Studies of three additional normal and BPH strains showed similar findings (shown in Fig. 2).

\section{Effect of TGF- $\beta 1$ on IGFBP-3 levels as detected by WLB}

$\mathrm{CM}$ was collected from confluent cultures maintained for $48 \mathrm{~h}$ in serum-free medium with or without TGF- $\beta 1$ $(0 \cdot 01-1 \cdot 0 \mathrm{ng} / \mathrm{ml})$. In Fig. 1 , it is observed that TGF- $\beta 1$ had a significant, dose-dependent stimulatory affect on the production of IGFBP-3 by normal PC-S. A similar effect is apparent in the BPH PC-S CM, but to a much lesser degree. The other IGFBPs in PC-S CM were not affected by TGF- $\beta$ treatment. Figure 2 shows a graphical representation of densitometric analysis of mean control and TGF- $\beta 1$-stimulated IGFBP-3 levels in the normal $(n=4$ 


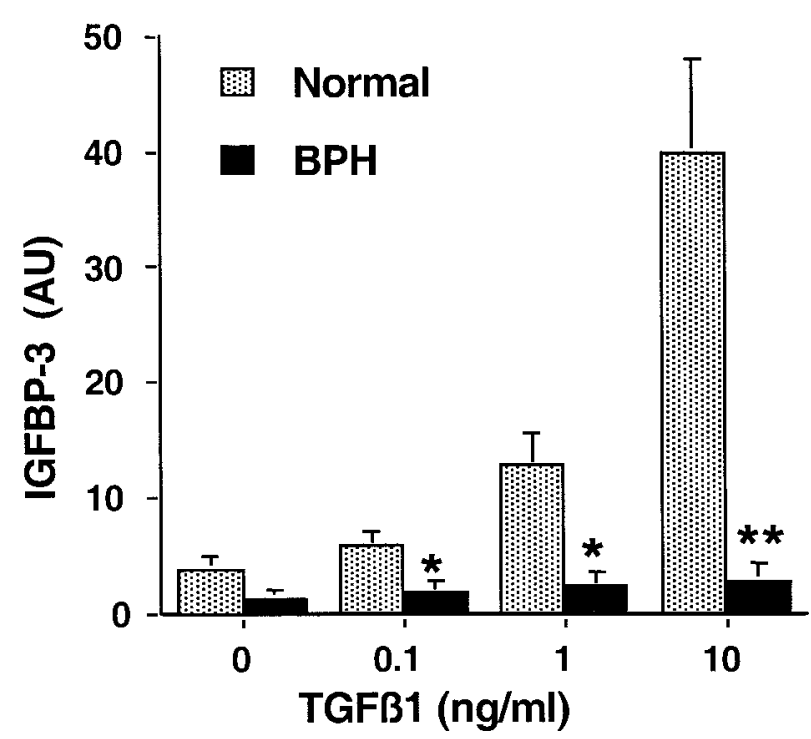

Figure 2 Induction of IGFBP-3 protein secretion by TGF- $\beta 1$ in prostate stromal cells. Densitometrically analyzed values of IGFBP-3 glycoprotein levels in the CM of normal $(n=3)$ and BPH $(n=3)$ PC-S are shown as mean \pm S.E.M. ${ }^{*} P<0 \cdot 01,{ }^{*} P<0 \cdot 001$ compared with normals.

strains) vs the BPH ( $n=4$ strains) PC-S CM. At baseline, the normal PC-S expressed 2-fold more IGFBP-3 than $\mathrm{BPH}$ PC-S ( $P=$ not significant $)$ and showed a dosedependent response to TGF- $\beta 1$. Remarkably, when maintained in the presence of $1.0 \mathrm{ng} / \mathrm{ml}$ TGF- $\beta 1$, the normal cells expressed 15-fold more IGFBP-3 than at baseline while the BPH PC-S grown in the same condition showed only a 2 -fold increase in IGFBP-3 levels. The normal PC-S, thus, appear to be six times more responsive to TGF- $\beta 1$-stimulation of IGFBP-3 than the BPH PC-S. Identical findings were observed by WIBs (data not shown).

\section{Immunocytochemistry}

Immunocytochemical analysis of IGFBP-3 was performed on control and TGF- $\beta 1$-treated cultures of normal and BPH PC-S. In Fig. 3, the control normal PC-S showed slight staining for IGFBP-3, whereas the control BPH PC-S had little IGFBP-3 staining. When treated with $1 \cdot 0 \mathrm{ng} / \mathrm{ml}$ TGF- $\beta 1$ for 3 days, the normal cells showed marked increase in staining for IGFBP-3. The BPH PC-S showed only a slight increase in staining for IGFBP-3, following treatment with TGF- $\beta 1$.

\section{Effects of TGF- $\beta 1$ on IGFBP-3 mRNA levels}

In order to determine the nature of TGF- $\beta 1$ regulation of IGFBP-3, Northern blot studies were conducted on total RNA from normal and BPH PC-S, both with and

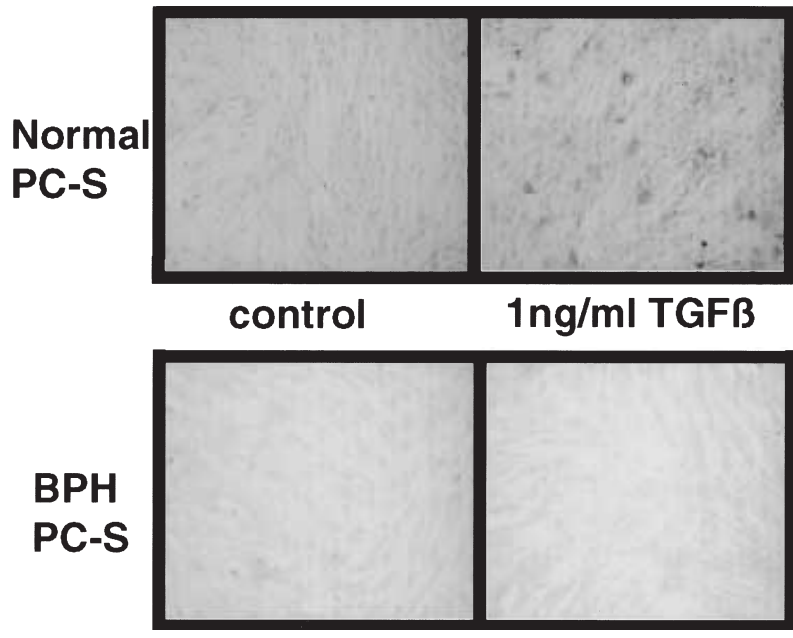

Figure 3 In situ induction of IGFBP-3 protein by TGF- $\beta 1$ in normal and BPH PC-S. Immunocytochemical staining with IGFBP-3 antibodies in normal and $\mathrm{BPH}$ cells are shown. Cultures grown to near confluency were treated for $48 \mathrm{~h}$ with $1 \mathrm{ng} / \mathrm{ml} \mathrm{TGF-} \beta 1$.

without TGF- $\beta 1$ treatment. Figure 4A depicts total RNA probed for IGFBP-3 message in the same normal and $\mathrm{BPH}$ PC-S cultures described earlier. Baseline IGFBP-3 mRNA levels appeared similar in normal and BPH cells. However, consistent with WLB and WIB findings, the normal PC-S were significantly more responsive to TGF- $\beta 1$ than BPH PC-S. As shown in Fig. 4B, phosphoimager analysis of three experiments on three normal and three $\mathrm{BPH}$ strains demonstrated that at $1.0 \mathrm{ng} / \mathrm{ml}$ TGF- $\beta 1$, normal PC-S IGFBP-3 mRNA levels were 5 -fold higher than those of BPH PC-S $(P<0 \cdot 001)$. This suggests that the increased levels of IGFBP-3 glycoprotein seen in the CM of normal TGF-stimulated PC-S cells are a result of increases in IGFBP-3 mRNA levels, but additional post-transcriptional mechanisms such as modulation of proteolysis or cellular uptake of IGFBP-3 may also contribute to the rise in the CM IGFBP-3 levels.

\section{Cell proliferation studies}

We and others have reported the dose-dependent inhibition of prostatic stromal growth by TGF- $\beta$ (Story et al. 1993, Kassen et al. 1996, Peehl \& Sellers 1997). Proliferation studies were performed to compare the responsiveness to TGF- $\beta 1$ of BPH and normal PC-S. Attenuated growth inhibition of BPH PC-S by TGF- $\beta 1$ paralleled the diminished induction of IGFBP-3 by TGF- $\beta 1$ in these cells. Cells were inoculated into serum-supplemented media with TGF- $\beta 1$ ranging from 0.001 to $1 \mathrm{ng} / \mathrm{ml}$. Ten days later, growth was quantified and compared with that in the absence of added TGF- $\beta 1$. Figure 5 shows that TGF- $\beta 1$ at $1 \mathrm{ng} / \mathrm{ml}$ suppressed the growth of normal PC-S strains $(n=5)$ by $68 \%$. In contrast, the same amount of TGF- $\beta 1$ inhibited the growth of BPH PC-S strains 
A
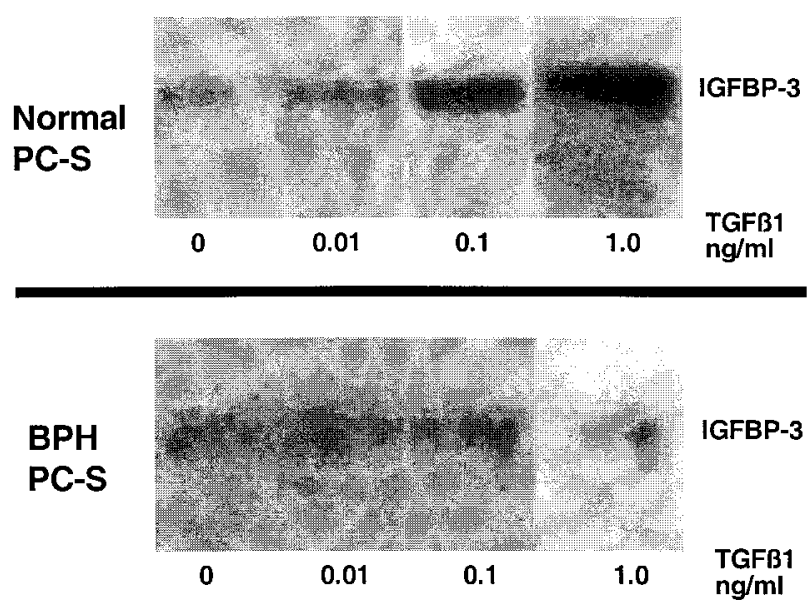

B

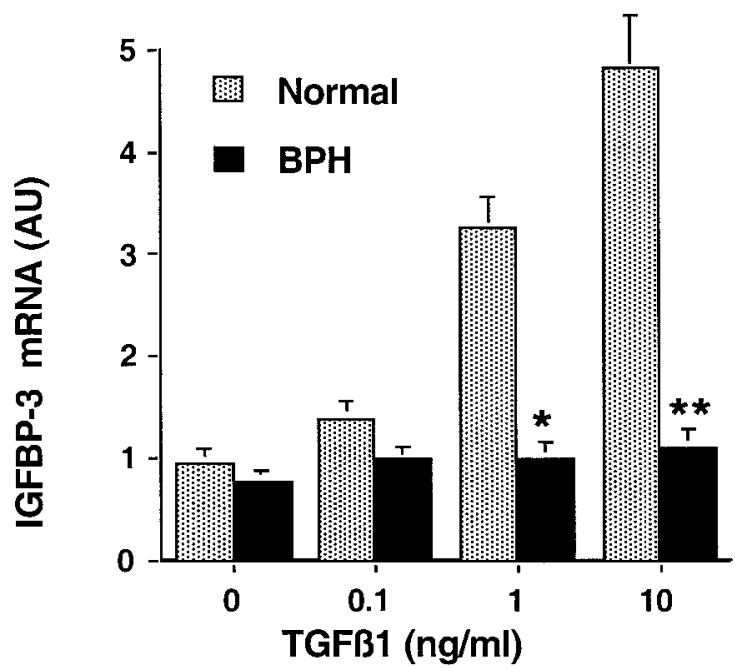

Figure 4 Induction of IGFBP-3 mRNA by TGF- $\beta 1$ in normal and BPH PC-S. (A) Northern blot analysis of total RNA extracts from normal and $\mathrm{BPH}$ stromal cells treated with varying doses of TGF- $\beta 1$ for $48 \mathrm{~h} ; 20 \mu \mathrm{g}$ per lane of total RNA were used and the blots were probed with the IGFBP-3 CDNA. (B) Phosphoimager analyzed normalized means \pm S.E.M. of three strains each of normal and BPH PC-S stimulated with TGF- $\beta 1$.

$(n=5)$ by only $26 \%$. Therefore, BPH PC-S were significantly less responsive than normal PC-S to the growthinhibitory activity of TGF- $\beta$, similar to their decreased response to TGF- $\beta$ induction of IGFBP-3 secretion.

\section{Identification of IGFBP-3 association proteins in PC-S}

Since IGFBP-3 has been shown to mediate the effects of TGF- $\beta$ in other types of cells by an IGF-independent

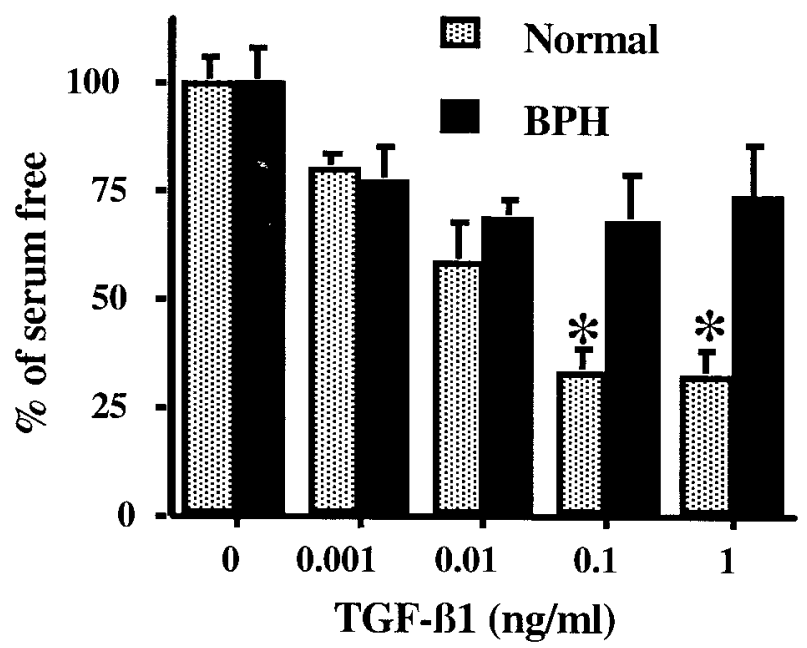

Figure 5 Growth inhibition of normal vs BPH PC-S by TGF- $\beta$. Five different strains each of normal PC-S and BPH PC-S were grown in the presence of varying concentrations of TGF- $\beta 1$ for 10 days. On the 10th day, growth was quantified. Shown are means \pm S.E.M. mechanism, we examined PC-S for the presence of candidate IGFBP-3 receptors/association proteins. Figure 6 shows a reverse ligand blot of normal and BPH PC-S cellular proteins. After separating the proteins by SDS-

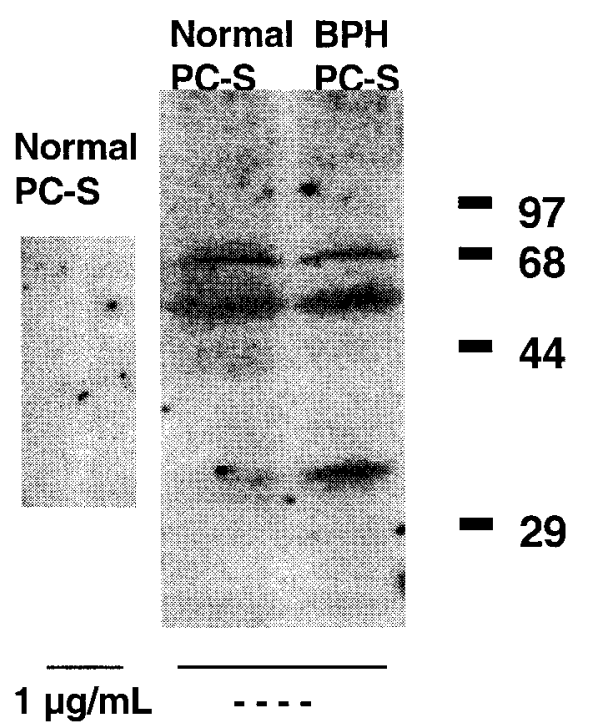

rhIGFBP-3 $\mathbf{1} \overline{\mathbf{\mu g} / \mathbf{m L}} \quad-\ldots$
Figure 6 Demonstration of putative IGFBP-3 receptors in PC-S cells. Reverse WLBs were performed on whole cell lysates which were run on $12 \%$ SDS-PAGE and blotted onto nitrocellulose membrane. The membrane was then incubated overnight with ${ }^{125}$ I-IGFBP-3. Bands at 35, 50 and $55 \mathrm{kDa}$ represent putative IGFBP-3 receptors. These bands are not seen in the presence of excess unlabeled IGFBP-3. 
PAGE, the proteins were transferred to a nitrocellulose membrane, which was hybridized with ${ }^{125} \mathrm{I}-$ IGFBP-3. The subsequent autoradiogram revealed three significant bands, present in protein extracts from both normal and BPH PC-S. These bands, all of nearly equal intensity, were approximately 36, 52 and $60 \mathrm{kDa}$. These putative IGFBP-3 receptors/association proteins may provide an IGF-independent pathway for IGFBP-3-mediated growth inhibition and are similar in size to the putative receptors/association proteins reported for IGFBP-3 by Rajah et al. (1997) and Oh et al. (1993b). There were no significant differences between the intensity of the bands when five BPH and five normal strains of PC-S were compared (data not shown). To determine the specificity of ${ }^{125}$ I-IGFBP-3 binding to its association proteins, nitrocellulose on which cell lysates from PC-S were electroblotted was incubated with ${ }^{125}$ I-IGFBP-3 in the presence of unlabeled excess $(1 \mu \mathrm{g} / \mathrm{ml})$ of glycosylated recombinant human IGFBP-3 resulting in a loss of the bands.

\section{Discussion}

In this study, we correlated changes in IGFBP-3 expression and secretion (by multiple methods) with the growthinhibitory activity of TGF- $\beta$ in several strains of normal and $\mathrm{BPH} \mathrm{PC}-\mathrm{S}$. We observed a dramatic induction of the growth-suppressing IGFBP-3 in normal strains, while only a slight induction was observed in BPH strains. Significantly, growth response to TGF- $\beta$ correlated with IGFBP-3 induction. At the highest tested concentration of $1 \mathrm{ng} / \mathrm{ml}$ TGF- $\beta 1$, normal PC-S showed a nearly $70 \%$ suppression of growth at 10 days relative to control conditions while BPH PC-S cell numbers were only reduced by $20 \%$ in response to TGF- $\beta 1$. While these two observations are merely correlative at this stage, we propose that the decreased induction of IGFBP-3 in BPH PC-S may lead to the abnormal growth inhibition by TGF- $\beta$ in this pathological state. We further suggest that the effects of IGFBP-3 in PC-S are mediated both by binding to endogenously produced IGF-II, whose secretion by PC-S we have previously demonstrated (Cohen et al. 1994a,b, Dong et al. 1997), and by binding directly to IGFBP-3 association proteins which we have now identified in PC-S.

The IGF axis is a critical component in the growth, differentiation and death of many cell types. The ontogeny and tissue-specific expression of the various components of the IGF axis are tightly regulated by hormonal, metabolic and genetic factors (Solberg \& Cohen 1996). Changes in these regulatory factors and the levels of IGF axis components in the cellular environment can have profound effects on cellular growth and proliferation. The prostate gland represents a microenvironment wherein IGF axismediated autocrine-paracrine growth regulation has been repeatedly demonstrated (Cohen et al. 1994a,b,
Angelloz-Nicoud et al. 1996, Dong et al. 1997, Hwa et al. 1997, Rajah et al. 1997).

Many agents have been identified as having growth modulating effects correlated with changes in IGFBP levels. Several trophic hormones have been shown to suppress IGFBP production by their target cells, suggesting that such suppression may be part of the stimulatory action of trophic peptides. These include thyroid-stimulating hormone in thyroid cells, follicle-stimulating hormone in Sertoli cells and granulosa cells and luteinizing hormone in Leydig cells (Solberg \& Cohen 1996). Conversely, many growth inhibitory agents have been shown to induce IGFBP production by target cells. These include vitamin- $\mathrm{D}_{3}$ in bone and prostate cells, tumor necrosis factor- $\alpha$ in fibroblasts, and retinoic acid in breast cancer cells (as reviewed in Solberg \& Cohen 1996). Most of these examples have been shown to be linked to regulation of the respective mRNA levels of the IGFBPs involved in the actions of the regulatory factors mentioned. The hypothesis commonly proposed regarding this highly regulated IGFBP secretion from cells is that local IGFBP levels govern the proliferation and survival of the cells by regulating the levels of free autocrine IGFs available to interact with the IGF receptor. Alternatively, we and others proposed that the levels of IGFBPs, particularly IGFBP-3, directly regulate cell growth and death via the recently proposed IGFBP-3 receptors/association proteins (Conover 1992, Cohen et al. 1993, Oh et al. 1993a, 1995, Valentinis et al. 1995, Angelloz-Nicoud et al. 1996, Gucev et al. 1996, Lalou et al. 1996, Neuenschwander et al. 1996, Gill et al. 1997, Karas et al. 1997, Leal et al. 1997, Mohseni-Zadeh \& Binoux 1997, Rajah et al. 1997, Rechler 1997, Zadeh \& Binoux 1997).

The results of our study provide a possible mechanism for the unregulated prostate cell growth observed in BPH. The potent inhibitory response of normal PC-S to TGF- $\beta$ concomitant with a strong induction of the growthinhibitory IGFBP-3 may be important in the regulation of prostate tissue growth and maintenance. The reduced response of $\mathrm{BPH}$ stromal cells to TGF- $\beta$ may represent a critical abnormality which plays an role in the growth dysregulation observed in $\mathrm{BPH}$ tissues.

We have previously proposed that reduction in the levels of the expression of the tumor suppressor transcription factor, WT-1, are related to the BPH phenotype (Dong et al. 1997). In that study we compared 25 strains of PC-S from normal, hyperplastic and malignant origins. WT-1 mRNA levels were reduced to $10 \%$ of normal in $\mathrm{BPH}$ PC-S strains, while no change was observed in cancer PC-S. IGF-II mRNA levels inversely correlated with WT-1 levels in that study, being 10-fold elevated, as did IGF-1R mRNA levels, being 3-fold elevated (Cohen et al. 1994a, Dong et al. 1997). WT-1 is known to regulate these two genes as well as additional target genes and specifically has been shown to regulate TGF- $\beta 1$ expression (Dey et al. 1994). It is unknown at this time whether 


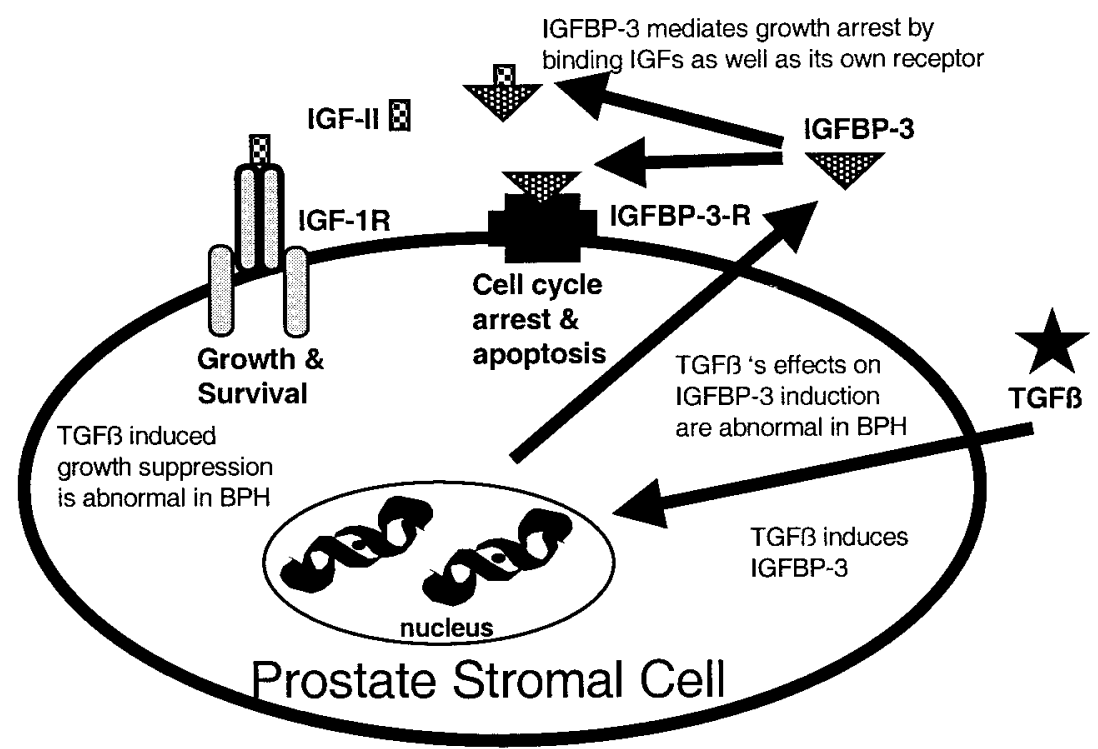

Figure 7 A theoretical model of TGF- $\beta$ action in PC-S and its abnormalities in BP-H. TGF- $\beta$ inhibits cell growth by stimulating IGFBP-3 secretion. IGFBP-3, in turn, acts to block IGF-dependent proliferation, as well as directly inhibiting growth via its own receptor. In $\mathrm{BPH}$, an impaired TGF- $\beta$ action on IGFBP-3 and growth inhibition is recognized.

the TGF- $\beta$ signal transduction cascade is regulated by WT-1. It is also unclear what role WT-1 plays in regulating IGFBP gene expression.

It is attractive to postulate that several IGFBPs including IGFBPs-2, -3 and -5 are WT-1 dependent as all three of these are dysregulated in $\mathrm{BPH}$ in the face of altered WT-1 levels (as seen in Fig. 1). Studying 19 different strains of PC-S, we have previously shown that the mRNA expression and protein secretion of IGFBP-2 is dramatically abolished in $\mathrm{BPH}$ vs normal and cancer strains (Cohen et al. 1994a). IGFBP-5, which is not seen in the secretions of normal PC-S strains, is present in significant amounts in BPH PC-S strains. These two genes are co-localized and tightly linked at chromosomal region 2q33-34 and may therefore be subject to coordinated regulation by WT-1 or other transcriptional regulators. Unlike the IGF-inhibitory nature of IGFBP-2, IGFBP-5 has been demonstrated to be growth enhancing in certain systems (Solberg \& Cohen 1996). Thus, multiple changes in the IGF axis are apparent in BPH stroma. Together, these molecular changes may be responsible for the dysregulated growth of the hyperplastic prostate. In our previous study of IGFBPs in BPH and normal PC-S strains (Cohen et al. 1994a), we did not observe significant differences in unstimulated IGFBP-3 levels in the CM from these two strain types. IGFBP-3 levels were approximately $35 \%$ lower at baseline in BPH strains. Similarly, IGFBP-3 levels were 50\% lower (but not statistically different) in $\mathrm{BPH}$ vs normal strains in the current study. The significant difference between normal and $\mathrm{BPH}$
IGFBP-3 levels was only apparent after TGF- $\beta 1$ stimulation. This observation also correlates with the finding that the altered growth phenotype of $\mathrm{BPH}$ only becomes manifest in an environment in which TGF- $\beta$ is present.

$\mathrm{BPH}$ is an extremely common disorder, affecting a large proportion of elderly men. The etiology of this condition remains unknown, but it appears to be related to local factors rather than to systemic hormonal changes. The trophic systems that may influence prostate growth, such as the androgenic and somatotrophic pathways, normally operate at a reduced, rather than increased tone at the age during which BPH develops. Histologically, the changes that occur in the hyperplastic prostate are reminiscent of a regression to a fetal-like state, and include a proliferation of the stroma followed by epithelial growth (McNeal 1990). The loss of IGFBP-3 response to TGF- $\beta$ in the prostatic stroma as well as the other described differences in the IGF axis are compatible with the above hypothesis. Our findings of abnormal TGF- $\beta$ response in cultured cells could well be related to increased proliferation in vivo.

In separate studies, we have shown the growth inhibition by TGF is accompanied by the induction of a smooth muscle cell phenotype (Peehl \& Sellers 1997). Preliminary studies with BPH PC-S indicate that TGF- $\beta$ induces smooth muscle differentiation equivalently in BPH and normal PC-S (D M Peehl, unpublished observations). This observation implies that the aberrant responses of BPH PC-S to TGF- $\beta$ in terms of IGFBP-3 secretion and growth inhibition that we have noted in the current study are not the result of loss of TGF- $\beta$ receptors. 
Instead, lack of induction of IGFBP-3 and loss of growth control by TGF- $\beta$ may be related to aberrations in downstream signaling events in BPH PC-S.

The nature of the TGF- $\beta$-induced growth inhibition of PC-S cells may involve the induction of either cell cycle arrest or apoptosis. In other cellular systems, TGF- $\beta$ is known to mediate both of these processes (Oh et al. 1995, Rajah et al. 1997). We and others have recently shown that IGFBP-3 directly mediates cell cycle arrest and apoptosis in fibroblasts derived from IGF-1 receptor knock-out mice (Valentinis et al. 1995, Rajah et al. 1997), in PC-3 prostate cancer cells (Rajah et al. 1997) and in breast cancer cells (Gill et al. 1997, Nickerson et al. 1997). The connection between IGFBP-3 and these processes is further substantiated by the fact that IGFBP-3 is a p53 response gene (Buckbinder et al. 1995, Friedlander et al. 1996, Ludwig et al. 1996). The ability of IGFBP-3 to regulate cell growth and death in environments which have IGF-I or IGF-II action via the IGF receptor is intuitive due to the well-described high-affinity binding of IGFBP-3 to the IGFs, which exceeds the affinity of IGFs to the IGF-1 receptor (Solberg \& Cohen 1996). Alternatively, IGF-independent actions of IGFBP-3 may be operative through binding to specific cell surface receptors/association proteins which may mediate (as yet uncharacterized) signal transduction leading to the described effects. These putative receptors, similar in their electrophoretic mobility to the IGFBP-3 association molecules we identified in Fig. 6, bind IGFBP-3 specifically, and with high affinity (Oh et al. 1993b). IGFBP-3 may also bind an additional molecules including the type $\mathrm{V}$ TGF- $\beta$ receptor, matrix and cell surface structures, or the IGF-1 receptor (Karas et al. 1997, Leal et al. 1997, Mohseni-Zadeh \& Binoux 1997).

In summary, as illustrated in the cartoon in Fig. 7, we have demonstrated that $\mathrm{PC}-\mathrm{S}$ strains isolated from patients with $\mathrm{BPH}$ harbor a defect in TGF- $\beta$ action on the induction of IGFBP-3. The reduced IGFBP-3 in BPH PC-S may lead to the observed decrease in the inhibitory effect of TGF- $\beta$ on PC-S growth seen in $\mathrm{BPH}$ strains. The action of IGFBP-3 on cell growth in PC-S may be mediated by binding to IGF-II or by interacting directly with IGFBP-3 receptors.

\section{Acknowledgements}

These studies were supported by grant 2RO1 DK47591 from NIH and an American Cancer Society idea development award.

\section{References}

Angelloz-Nicoud P, Harel L \& Binoux M 1996 Recombinant human insulin-like growth factor (IGF) binding protein-3 stimulates prostate carcinoma cell proliferation via an IGF-dependent mechanism. Role of serine proteases. Growth Regulation 6 130-136.
Angervo M, Koistinen R, Suikkari AM \& Seppala M 1991 Insulin-like growth factor binding protein-1 inhibits the DNA amplification induced by insulin-like growth factor-I in human granulosa luteal cells. Human Reproduction 6 770-773.

Buckbinder L, Talbott R, Velasco-Miguel S, Takenaka I, Faha B, Seizinger BR \& Kley N 1995 Induction of the growth inhibitor IGF-binding protein 3 by p53. Nature 377 646-649.

Cazals V, Mouhieddine B, Maitre B, Le Bouc Y, Chadelat K, Brody JS \& Clement A 1994 Insulin-like growth factors, their binding proteins, and transforming growth factor-beta 1 in oxidant-arrested lung alveolar epithelial cells. Journal of Biological Chemistry 269 14111-14117.

Cohen P, Peehl DM, Lamson G \& Rosenfeld RG 1991 Insulin-like growth factors (IGFs), IGF receptors and IGF binding proteins in primary cultures of prostate epithelial cells. Journal of Clinical Endocrinology and Metabolism 73 401-407.

Cohen P, Lamson G, Okajima T \& Rosenfeld RG 1993 Transfection of the human insulin-like growth factor binding protein-3 gene into Balb/c fibroblasts inhibits cellular growth. Molecular Endocrinology 7 380-386.

Cohen P, Peehl DM, Hintz RL \& Rosenfeld RG 1994a Insulin-like growth factor axis abnormalities in cultures of prostate stromal cells from patients with benign prostatic hypertrophy. Journal of Clinical Endocrinology and Metabolism 79 1410-1415.

Cohen P, Peehl DM \& Rosenfeld RG $1994 b$ The insulin-like growth factor axis in the prostate. Hormone and Metabolic Research 26 81-84.

Conover CA 1992 Potentiation of insulin-like growth factor (IGF) action by IGF-binding protein-3: studies of underlying mechanism. Endocrinology 130 3191-3199.

Dey BR, Sukhatme VP, Roberts AB, Sporn MB, Rauscher FJ \& Kim SJ 1994 Repression of the transforming growth factor-beta 1 gene by the Wilms' tumor suppressor WT-1 gene product. Molecular Endocrinology 8 595-602.

Dong G, Rajah R, Vu T, Hoffman AR, Rosenfeld RG, Roberts CT Jr, Peele DM \& Cohen P 1997 Decreased expression of the Wilm's tumor suppressor gene WT1 and increased IGF-II and IGF-1R in the prostatic stroma of patients with benign prostatic hyperplasia. Journal of Clinical Endocrinology and Metabolism 82 2198-2203.

Durham SK, Riggs BL \& Conover CA 1994 The insulin-like growth factor-binding protein-4 (IGFBP-4)-IGFBP-4 protease system in normal human osteoblast-like cells: regulation by transforming growth factor-beta. Journal of Clinical Endocrinology and Metabolism 79 $1752-1758$.

Elgin RG, Busby WH \& Clemmons DR 1987 An insulin-like growth factor binding protein enhances the biological response to IGF-I. Proceedings of the National Academy of Sciences of the USA $\mathbf{8 4}$ 3254-3258.

Friedlander P, Haupt Y, Prives C \& Oren M 1996 A mutant p53 that discriminates between p53-responsive genes cannot induce apoptosis. Molecular and Cellular Biology 16 4961-4971.

Gill ZP, Perks CM, Newcomb PV \& Holly JM 1997 Insulin-like growth factor-binding protein (IGFBP-3) predisposes breast cancer cells to programmed cell death in a non-IGF-dependent manner. Journal of Biological Chemistry 272 25602-25607.

Gucev ZS, Oh Y, Kelley KM \& Rosenfeld RG 1996 Insulin-like growth factor binding protein 3 mediates retinoic acid- and transforming growth factor beta 2-induced growth inhibition in human breast cancer cells. Cancer Research 56 1545-1550.

Guo YS, Townsend CM, Jin GF, Beauchamp RD \& Thompson JC 1995 Differential regulation by TGF-beta 1 and insulin of insulinlike growth factor binding protein-2 in IEC-6 cells. American Journal of Physiology 268 E1199-E1204.

Han G-R, Dohi DF, Lee H-Y, Rajah R, Walsh GL, Ki Hong W, Cohen P \& Kurie JM 1997 All-trans-retinoic acid increases transforming growth factor- $\alpha 2$ and insulin-like growth factor binding protein-3 expression through a retinoic acid receptor- $\alpha$ dependent signaling pathway. Journal of Biological Chemistry 272 13711-13719. 
Hwa V, Oh Y \& Rosenfeld RG 1997 Insulin-like growth factor binding protein- 3 and -5 are regulated by transforming growth factor-beta and retinoic acid in the human prostate adenocarcinoma cell line PC-3. Endocrine 6 235-242.

Karas M, Danilenko M, Fishman D, LeRoith D, Levy J \& Sharoni Y 1997 Membrane-associated insulin-like growth factor-binding protein-3 inhibits insulin-like growth factor-I-induced insulin-like growth factor-I receptor signaling in Ishikawa endometrial cancer cells. Journal of Biological Chemistry 272 16514-16520.

Kassen A, Sutkowski DM, Ahn H, Sensibar JA, Kozlowski JM \& Lee C 1996 Stromal cells of the human prostate: initial isolation and characterization. Prostate 28 89-97.

Lalou C, Lassarre C \& Binoux M 1996 A proteolytic fragment of insulin-like growth factor (IGF) binding protein-3 that fails to bind IGFs inhibits the mitogenic effects of IGF-I and insulin. Endocrinology 137 3206-3212.

Leal SM, Liu Q, Huang SS \& Huang JS 1997 The type V transforming growth factor beta receptor is the putative insulin-like growth factor-binding protein 3 receptor. Journal of Biological Chemistry 272 20572-20576.

Ludwig RL, Bates S \& Vousden KH 1996 Differential activation of target cellular promoters by p53 mutants with impaired apoptotic function. Molecular and Cellular Biology 16 4952-4960.

Martin JL \& Baxter RC 1991 Transforming growth factor-beta stimulates production of insulin-like growth factor-binding protein-3 by human skin fibroblasts. Endocrinology 128 1425-1433.

Martin JL, Ballesteros M \& Baxter RC 1992 Insulin-like growth factor-I (IGF-I) and transforming growth factor-beta 1 release IGF-binding protein-3 from human fibroblasts by different mechanisms. Endocrinology 131 1703-1710.

McCusker RH \& Clemmons DR 1994 Effects of cytokines on insulin-like growth factor-binding protein secretion by muscle cells in vitro. Endocrinology 134 2095-2102.

McNeal JE 1990 Pathology of benign prostatic hyperplasia: insight into etiology. Urologic Clinics of North America 17 477-486.

Mohseni-Zadeh S \& Binoux M 1997 Insulin-like growth factor (IGF) binding protein-3 interacts with the type 1 IGF receptor, reducing the affinity of the receptor for its ligand: an alternative mechanism in the regulation of IGF action. Endocrinology 138 5645-5648.

Neuenschwander S, Schwartz A, Wood TL, Roberts CT Jr, Henninghausen L \& LeRoith D 1996 Involution of the lactating mammary gland is inhibited by the IGF system in a transgenic mouse model. Journal of Clinical Investigation 97 2225-2232.

Nickerson T, Huynh H \& Pollak M 1997 Insulin-like growth factor binding protein-3 induces apoptosis in MCF7 breast cancer cells. Biochemical and Biophysical Research Communications 237 690-693.

Oh Y, Muller HL, Lamson G \& Rosenfeld RG 1993a Insulin-like growth factor (IGF)-independent action of IGF-binding protein-3 in Hs578T human breast cancer cells. Cell surface binding and growth inhibition. Journal of Biological Chemistry 268 14964-14971.

Oh Y, Muller HL, Pham H \& Rosenfeld RG 1993 bemonstration of receptors for insulin-like growth factor binding protein-3 on
Hs578T human breast cancer cells. Journal of Biological Chemistry $26826045-26048$.

Oh Y, Muller HL, Ng L \& Rosenfeld RG 1995 Transforming growth factor-beta-induced cell growth inhibition in human breast cancer cells is mediated through insulin-like growth factor-binding protein-3 action. Journal of Biological Chemistry 270 13589-13592.

Peehl DM 1992 Cultures of human prostatic epithelial cells. In Culture of Epithelial Cells, pp 159-180. Ed RI Freshney. New York: Wiley-Liss.

Peehl DM \& Sellers RG 1997 Induction of smooth muscle cell phenotype in cultured human prostatic stromal cells. Experimental Cell Research 232 208-215.

Rajah R, Valentinis B \& Cohen P 1997 Insulin-like growth factor (IGF)-binding protein-3 induces apoptosis and mediates the effects of transforming growth factor-beta1 on programmed cell death through a p53- and IGF-independent mechanism. Journal of Biological Chemistry 272 12181-12188.

Rechler MM 1997 Growth inhibition by insulin-like growth factor (IGF) binding protein-3 - what's IGF got to do with it? Endocrinology 138 2645-2647.

Solberg P \& Cohen P 1996 The role of the insulin-like growth factor binding proteins and their proteases in modulating IGF action. Endocrinology and Metabolism Clinics of North America 25 591-614.

Story MT, Hopp KA, Meier DA, Begun FP \& Lawson RK 1993 Influence of transforming growth factor $\beta 1$ and other growth factors on basic fibroblast growth factor level and proliferation of cultured humane prostate-derived fibroblasts. Prostate 22 183-197.

Tsukazaki T, Usa T, Matsumoto T, Enomoto H, Ohtsuru A, Namba H, Iwasaki K \& Yamashita S 1994 Effect of transforming growth factor-beta on the insulin-like growth factor-I autocrine/paracrine axis in cultured rat articular chondrocytes. Experimental Cell Research 215 9-16.

Valentinis B, Bhala A, DeAngelis T, Baserga R \& Cohen P 1995 The human insulin-like growth factor (IGF) binding protein-3 inhibits the growth of fibroblasts with a targeted disruption of the IGF-I receptor gene. Molecular Endocrinology 9 361-367.

Yateman ME, Claffey DC, Cwyfan Hughes SC, Frost VJ, Wass JA \& Holly JM 1993 Cytokines modulate the sensitivity of human fibroblasts to stimulation with insulin-like growth factor-I (IGF-I) by altering endogenous IGF-binding protein production. Journal of Endocrinology 137 151-159.

Zadeh SM \& Binoux M 1997 The 16-kDa proteolytic fragment of insulin-like growth factor (IGF) binding protein-3 inhibits the mitogenic action of fibroblast growth factor on mouse fibroblasts with a targeted disruption of the type 1 IGF receptor gene. Endocrinology 138 3069-3072.

Received 3 May 1999

Accepted 29 September 1999 